\title{
CONGENITAL HYDRONEPHROSIS: DISEASE OR CONDITION?
}

\section{Mile Petrovski, Risto Simeonov, Lazar Todorovikj, Vladimir Chadikovski, Shaban Memeti, Branka Petrovska, Toni Risteski, Vesna Cvetanovska}

University Clinic of Paediatric Surgery, Medical Faculty, Ss. Cyril and Methodius University, Skopje, R. Macedonia

Corresponding Author: Mile Petrovski, University Clinic of Paediatric Surgery, Medical Faculty, Vodnjanska 17, 1000 Skopje, Tel. + 389 (0)2 31470 43, E-mail: milep22@yahoo.com

\begin{abstract}
The aim of this paper is to address the dilemmas of the paediatric surgeon when facing an isolated, unilateral, congenital hydronephrosis and discuss the strategic options for the management of this condition.

Congenital hydronephrosis, the most commonly diagnosed uropathy in children, is usually a benign and self-resolving condition. Nonobstructive hydronephrosis does not require operative treatment, while timely treatment is imperative for obstructive hydronephrosis before significant renal damage ensues. Managing congenital hydronephrosis is a challenging task.

Thirty-two children with unilateral, isolated hydronephrosis and nonobstructed renography curves were followed up for 3 years.

On the initial evaluation according to the grade of hydronephrosis: $22.6 \%$ were grade I, $54.8 \%$ grade II and $22.6 \%$ grade III. After 12 months of follow-up: $30 \%$ were grade I, $51.5 \%$ grade II and $18.5 \%$ grade III, respectively. After the three-year follow-up, there were no hydroneproses greater than grade II. The mean value of the separate GFR of the affected kidney at initial evaluation was $42.83 \%$, and $40.33 \%$ after three years. In three children the treatment was converted from conservative to surgical. Nonobstructive, congenital hydronephrosis is a benign condition not requiring any medical treatment, but aggressive observation is indicated.
\end{abstract}

Key words: congenital hydronephrosis, management, child.

\section{Introduction}

The term "hydronephrosis" is derived from the Greek words: hydro = water, nephros = kidney and osis = condition. Hydronephrosis is a descriptive, anatomic entity, defined as an increased capacity of the renal collecting system, and signifies dilatation of the renal pyelon and/or calices of one or both kidneys [1]. The dilatetion of the upper urinary tract can result from: obstruction, vesicoureteral reflux, a diuretic phenomenon or it can be the consequence of a spontaneous or operative resolution of a developmental anomaly [2]. Thus, hydronephrosis is the most significant consequence of urinary tract obstruction. Clearly, though closely rela- ted, hydronephrosis and obstruction are not synonyms and should not be used as such [3].

Fetal uropathies are detected with ultrasound in $1 \%$ of adequately monitored pregnancies, and $50 \%$ of these are hydronephroses [4].

The kidneys compensate physiological stresses by renal vascular autoregulation, shifts in the glomerulo-tubular balance, compensatory renal hypertrophy and tubular hyperfiltration. In the face of urinary tract obstruction, mechanical adaptive mechanisms (dilatation of the collecting system - hydronephrosis) add up to the physiological compensatory responses in order to create a reservoir and buffer the raised pressures generated by the obstruction. When 
the physiological and anatomical limits of the adaptive responses are breached, a pathological condition develops [5]. In the non-obstructed urinary tract, the urine is transported throughout the whole physiological span, there are no deformational changes and the intraluminal pressures are not elevated, therefore the musculature of the renal pelvis as well as the renal parenchyma are not offended. The effects of the chronic obstruction are: hydronephrosis, atrophy of the renal parenchyma and decreased renal function [6]. Hence, the term obstructive uropathy applies to the renal parenchymal damage caused by the presence of obstruction at any level of the urinary tract [7]. The decrease in the renal function cannot be simply attributed to the mechanical compression exerted by the retained urine. The contemporary understanding of the pathology is that the obstructive uropathy produces obstructive nephropathy via a haemodynamic, cascade reaction which accounts for an ichemic injury [1]. The order of pathohystological events being: tubular dilatation, interstitial fibrosis and tubular sclerosis.

During the early phases of the development of the embryo, the ureter becomes obliterated by the epithelial proliferation. Recanalisation begins after the sixth week of gestation, starts in the middle portion and gradually progresses proximally and distally [8]. Transitory hydronephroses can be embryologically explained with the delayed disappearance of the Chwalla-like ureterovesical membranes, the embryonal plicae and kinks, as well as the embrional and aberrant blood vessels [1]. Taking such embryological reasoning into consideration: hydronephrosis, parenchymal atrophy and decreased renal function observed postnatally in a kidney might in actuality be the residuum of some of the aforementioned embryologic disturbances which eventually resolved spontaneously, and in fact, the kidney may not be obstructed [9].

Congenital hydronephrosis is one of the most common entities in paediatric urology practice. Its monitoring and management is a challenging clinical task on several levels. The most important question to be answered is whether the dilatation of the collecting system is a result of obstruction. If an obstruction cannot be precisely defined, two approaches emerge: one is based on expectation, follow-up for renal deterioration (which is clearly not the ideal solution) and the other is employing diagnostic procedures to target the presence of obstruction. Furthermore, the paediatric urologist has to define the functional significance of the hydronephrosis; to choose between the options to operate or to manage the patient on conservative grounds; to decide the most suitable timing for surgical intervention; and finally to choose the most suitable modalities for follow-up.

The aim of this paper is to address the dilemmas of the paediatric surgeon when facing unilateral congenital hydronephrosis and discuss the strategic options for the management of this condition, based on the established practical criteria.

\section{Material and method}

The analysed sample included 32 children aged from 0 to 14 years, with isolated, unilateral congenital hydronephrosis. Vesicoureteral reflux and subvesical obstruction were exluded in all patients with miction urethracystography. Transabdominal ultrasound was used to grade the hydronephrosis. The ubiquitous system proposed by the Society of Fetal Urology in 1993, which grades hydronephrosis from $0-I V$, was used as a grading system. In the patients with prenatally diagnosed hydronephrosis, the initial ultrasound exam was performed on the second postnatal day in order to avoid obtaining false negative results due to the expected low urinary output in the setting of the physiological dehydration of the newborn. Dynamic renography was performed using $99 \mathrm{~m}$ Tc-DTPA as a radiotracer, with the application of $1 \mathrm{mg} / \mathrm{kg}$ Furosemide. We recorded: 1) The type of the generated curve for both kidneys before and after the application of the diuretic; 2) The halftime of contrast elimination (T1/2) in minutes; 3$)$ The relative function of each kidney (separate GFR, or $\%$ of contribution to the global renal function); and 4) The difference in GFR between the healthy and the affected kidney in percenttage $(\%)$. The results obtained with diuretic radiorenography should delineate the presence or absence of obstruction. This is considered a gold standard. Unfortunately in more than one quarter of cases the results are equivocal. Our study included only the children with nonobstructive renographic curves. 
Ultrasound was repeated at 3,6 and 12 months after the initial evaluation and yearly during the successive two years of follow-up. Radionuclide imaging was performed at the initial evaluation and yearly thereafter.

Children with hydronephrosis and no clinical signs of urinary infection were simply observed. Children with symptoms and those with a positive urinary culture were treated with appropriate antibiotics.

In three children the treatment strategy was converted to operative management due to severe urinary tract infections (two patients) and difference in the value of the separate GFR's of the affected and the healthy kidney greater than $10 \%$ coupled with progression of the hydronephrosis (one patient).

\section{Results}

The mean age of the children in the analysed group at presentation was 18 months. Twenty children were boys and 12 were girls. Hydronephrosis was left-sided in 18, and rightsided in 14 patients. Prenatally diagnosed hydronephrosis was the motive for paediatric urological consultation in only 12 patients. Other patients were brought to medical attention with the following presenting symptoms: palpable flank mass (1); abdominal pain (5); gastrointestinal symptoms (8); urinary tract infection (3) and haematuria (3).

On the initial evaluation according to the grade of hydronephrosis: $22.6 \%$ were grade I, $54.8 \%$ grade II and $22.6 \%$ grade III. After 12 months of follow-up: $30 \%$ were grade I, $51.5 \%$ grade II and $18.5 \%$ grade III, respectively. After the three year follow-up, there were no hydronephroses greater than grade II. According to these results, there is a residual hydronephrosis not requiring surgical treatment in almost all children, with the most common being grade II.

The mean value of the separate GFR of the affected kidney at initial evaluation was $42.83 \%$, and $40.33 \%$ after three years. The recorded decrease in the function of the affectted kidneys is considered insignificant according to the literature $[10,11]$. In three children the renal function improved by $12 \%, 13 \%$ and $28 \%$, while in the rest the renal function was stabile (in the range of $-5 \%$ to $+28 \%$ ). In the three patients who were initially treated con- servatively and were operated later on, HynesAnderson pyeloplasty was performed.

\section{Discussion}

Until the eighth decade of the last century, children diagnosed with hydronephrosis presenting with abdominal mass, urinary infection, haematuria or renal colic, were unequivocally considered to have a ureteropelvic obstruction, and as such were inevitably subjected to surgical treatment. The technological proliferation of the ultrasound techniques and their implementation in the standard antenatal screening praxis led to increased diagnosis of urinary tract dilatation (in up to $1 \%$ of the monitored pregnancies, half of which were isolated hydronephroses) [4]. Furthermore, it revealed a large discrepancy between the incidence of detected hydronephroses and the well determined incidence of ureteropelvic junction stenoses $(1: 1500$ children) [12]. In the material we presented, hydronephrosis was diagnosed prenatally in only 12 children $(37.5 \%)$. As a comparison, in most of the developed countries the detection of hydronephrosis during pregnancy exceeds $90 \%$ [13].

Transient, physiological hydronephrosis is by far the most common form detected antenatally. It constitutes up to $76 \%$ of all cases $[14,15]$. The majority of antenatal hydronephroses resolve spontaneously in the third trimester of pregnancy and early infancy [16-18]. The explaining mechanism of this spontaneous resolution lies in the transitional (antenatal, postnatal) renal physiology and the histo anatomy of the developing ureter. The production of urine by the foetus begins from the tenth week of gestation. During this phase the basic role of urine production is participation in the amniotic fluid, as an essential factor contributing to the development of the lungs. On the other hand, the basic renal functions are accomplished through the placenta. Although the foetal kidney is the precursor of the postnatal kidney, they differ from a physiological standpoint and they also respond to obstruction in a distinct manner [19, 20]. Some of the possible explanations for the spontaneous resolution of hydronephrosis include: 1) Foetal urine production is 4 to 6 times greater compared to the postnatal production, due to the differences in renovascular resis- 
tance, glomerular filtration rate and the concentration ability, causing the effect of dilatation, similar to the diuretic phenomenon encountered with diabetes insipidus; 2) The increased compliance of the ureter, owing to its tortuous configuration and the difference in deposition of collagen and elastin fibres. Both of these conditions resolve pre- or postnatally and can therefore be the reason for transient hydronephrosis; 3) Persistent ureteral plicae; 4) Delayed establishment of normal peristalsis $[21,22]$. Partial obstructions can further be compensated by renovascular autoregulation, changes in the glomerulo-tubular balance or compensatory renal hypertrophy. The mechanical compensatory mechanism consists of dilatation of the collecting system (hydronephrosis) in such a manner that equilibrium is achieved: the dilated pyelon has increased compliance and low intrapelvic pressure so it easily counteracts the increased volume.

Finally, some of the prenatally and postnatally diagnosed hydronephroses are obstructtive. According to the literature $10-20 \%$ of the prenatally diagnosed hydronephroses will eventually require surgical treatment [23].

A significant ureteropelvic junction stenosis accounts for approximately $10 \%$ of prenatal hydronephroses [24]. Ureteropelvic junction obstruction can be caused by extrinsic (bands, kinks or aberrant vessels), intrinsic (stenosis, discontinuity of the muscle layer with the presence of aperistaltic ureteral segment) or combined causes. Ureterovesical junction obstruction constitutes about $4 \%$ of the causes of neonatal hydronephrosis. Posterior urethral valves, multicystic dysplastic kidneys and ureterocele constitute between $2 \%$ and $4 \%$ of the cases [24]. Vesicoureteral reflux is found in $33 \%$ of cases of prenatal hydronephrosis [23]. Males predominate in the last group, and some series report up to $65 \%$ spontaneous resolution of hydronephrosis in these infants, including a remarkable number of severe grades IV and V reflux [24].

If viewed as anatomic entity, hydronephrosis is a benign condition. Obstruction which leads to obstructive uropathy on the other hand seriously impinges on renal function. Thereby arises the need to distinguish these two entities. The task could be easily solved by adding the appropriate diagnostic tool to the equation. Unfortunately, the modern medicine of our time lacks such a gold standard. Attempts have been made to tackle the dilemma by various eminent schools of thought. Back in 1975, Mayor et al. [26] conducted an elegant study including children with bilateral and unilateral obstruction, and concluded: 1) If the obstruction is addressed surgically before the child turns 12 months of age, the renal function will improve; 2) If an operation is conducted between the first and second years of life, the renal function will arrest the deterioration path; 3) Children older than 2 years of age are expected to experience progressive worsening of the renal function despite operative intervention. Motivated by the former acknowledgements, in 1984 King et al. [2] conducted pyeloplasties in newborns with prenatally verified hydronephrosis and obstructive type of renography curves, obtaining excellent results. Nevertheless, their approach was criticised since it was not clear whether the result reflect the effect of the operative treatment or the spontaneous resolution of the hydronephrosis.

In the attempt to limit the number of operated children Ransley et al. [27], included the separate function of the affected kidney (GFR) as a decision-making criterion. They arbitrarily choose the separate function (renographic measurement of GFR) $>40 \%$ to be the criterion to treat conservatively. Also, the loss of $>10 \%$ of the separate function during follow-up would indicate operative treatment. Other authors have different opinions on the value of GFR for the affected kidney as a marker for conservative treatment. According to Blyth [28] the limit is $35 \%$, while Kass et al. [29] take $45 \%$ of obtainned separate function to be the value indicative for conservative treatment. In 1998, Ransley, Dhillon et al. [30] deepened their research, striving to identify children with good function $(>40 \%)$ who would require operative management later on. By measuring the antero-posterior diameters of the renal pelvis, they demonstrated that all children with renal pelvis diameters $<12 \mathrm{~mm}$ will improve spontaneously, while those with diameters $>50 \mathrm{~mm}$ will eventually require operative treatment. The expectative approach was radicalised by Koff [31], who treated 107 infants with hydronephrosis 
conservatively, irrespective of the degree of hydronephrosis on the ultrasound and urography, the value of separate GFR, or the type and T1/2 of the renography curve. Koff based his study on the assumption that the reduced percentage of the separate GFR is the result of the intrauterine change of the hydronephrotic kidney, and it does not point to whether the obstruction has spontaneously resolved or not. Of the 107 infants in this series, seven required surgical intervention (6 of the group with good parameters according to the other authors, and 1 from 16 in the group with unfavourable parameters).

Based on the presented literature and the results we obtained from our study, we recommend an algorithm for follow-up and management of children with prenatally diagnosed hydronephrosis (Figure 1).

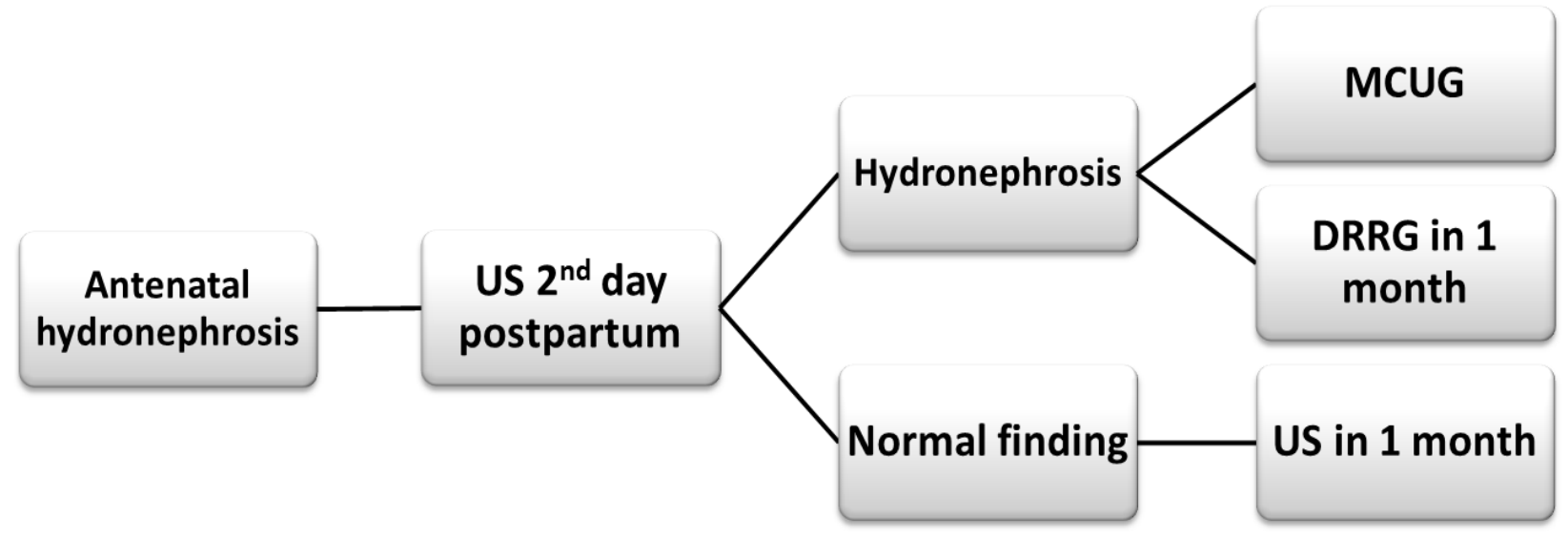

Figure 1 - Management of antenatally diagnosed hydronephrosis. US = ultrasound; $M C U G=$ miction (voiding) urethrocystography should be performed in the newborns with hydronephrosis to exclude vesicourinary reflux and subvesical obstruction; DRRG = diuretic (dynamic) radiorenography

The criterion for the diagnosis of obstruction in a hydronephrotic kidney should be an obstructive curve generated with dynamic renography. For children with nonobstuctive hydronephrosis another parameter should be added to the algorithm: the GFR value of the affected kidney. Separate GFR values of $<10 \%$ should indicate a DMSA scan, and a nephrostomy or nephrectomy would be employed according to the results of the scan (Figure 2).

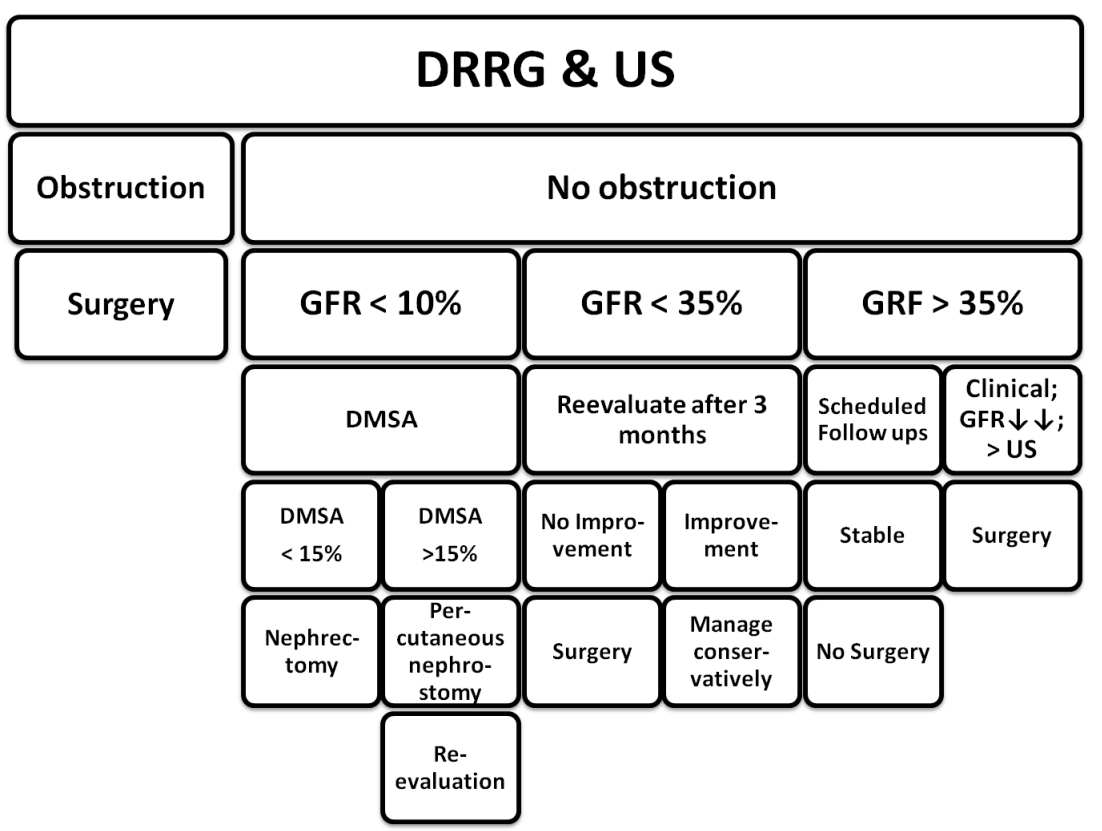

Figure 2 - Management of the child with unilateral, congenital hydronephrosis. $G F R=$ separate glomerular filtration rate; $U S=$ ultrasound; DMSA = dimercaptosuccinic acid radionuclide scan 
The borderline value for the GFR in the proposed schematic treatment is $35 \%$. If GFR $<35 \%$ reevaluation should follow after 3 months. If the function does not improve, these children should be operated regardless of other findings. We justify this seemingly radical attitude because of the frustrating truth, that while no gold standard to determine the presence of obstruction exists, further deterioration could lead to complete afunction. In this scenario, operative treatment not only removes the obstruction, but also allows for the activation of the renal potential. This potential does not solely apply to regenerative changes, but to the actual 'awakening' of the inherent potential of the kidney to grow and develop. Since this is a quality somehow unique to the period of infancy, such a radical approach may not be obligatory in older children. In cases of GFR $>35 \%$ children should be followed up according to the scheme: ultrasound at 3, 6, 12 months after initial presentation, and yearly thereafter. Diuretic renography is performed during the initial work-up, and yearly thereafter. Of course, the emergence of clinical symptoms dictates additional investigations in accordance with the clinical context. If, during observation, the difference in separate GFR is $>10 \%$, coupled with progression of the hydronephrosis on US (exactly the case in one of our patients) or significant clinical symptoms are present (two children in our group with severe urinary tract infections) surgical treatment is indicated.

\section{Conclusion}

The key to the appropriate management of children with isolated, unilateral congenital hydronephrosis is to select patients correctly for operative or expectative treatment, therefore aggressive observation is recommended. With the proposed strategic approach we hope that we will get one step closer to reaching the ideal: not one unnecessary surgery plus and not one single kidney lost.

\section{REFERENCES}

1. Tripp BM, Homsy YL. Neonatal hydronephrosis- the controversy and management. Pediatr Nephrol. 1995; 9: 503-9.
2. Flashner SC, King LR. Ureteropelvic junction. In: Kelalis PP, King LR, Belman AB. Clinical pediatric urology. Philadelphia; W. B. Saunders, 1992; 693-723.

3. Homsy YL, Williot P, Danais S. Transitional neonatal hydronephrosis: fact or fantasy? J Urol. 1986; 136: 339-41.

4. Thomas DFM. Fetal uropathy. Br J Urol. 1990; 66: 225-31.

5. Koff SA, Hayden LJ, Cirulli C, Shore R. Pathophysiology of ureteropelvic junction: experimental and clinical observations. J Urol. 1986; 136: 336-8.

6. Weiss RM. Obstructive uropathy: pathophysiology and diagnosis. In: Kelalis PP, King LR, Belman AB: Clinical pediatric urolgy. Philadelphia; W. B. Saunders, 1992; 664-82.

7. Gulmi FA, Felsen D, Vaughan ED. Pathophysiology of urinary tract obstruction. In Walsh PC, Retik BA, Vaughan ED, Wein AJ: Campbell's Urology $8^{\text {th }}$ ed. CD-ROM Vol 1. Chapt.12. Philadelphia; Saunders, 2003.

8. Ruano-Gil D, Coca-paueras A, Tejedo-Maten A. Obstruction and normal recanalisation of the ureter in the human embryo: its relation to congenital ureteral obstruction. Uer Urol. 1975; 1: 287.

9. Nguyen HT, Kogan BA. Upper urinary tract obstructtion: experimental and clinical aspects. $\mathrm{Br} \mathrm{J}$ Urol. 1998; 81: 13-21.

10. Neste MG, Du Cret RP, Finlay DE, Sane S, Gonzalez R, Boudreau RJ, Kuni CC. Postoperative diuresis renography and ultrasound in patients undergoing pyeloplasty, predictors of surgical outcome. J Nucl Med. 1993; 18: 872-876.

11. Steiner D. Steiss JO, Klett R, Miller J, Bauer R, Weidner W, Rascher W. The value of renal scintigraphy during controlled diuresis in children with hydronephrosis. Eur J Nucl Med. 1999; 26: 18-21.

12. Brand JR, Kaminopetros P, Cave M, Irving HC, Lilford RJ. Specificity of antenatal ultrasound in the Yorkshire region: a prospective study of 2261 ultrasound detected anomalies. Br J Obstet Gynaecol. 1994; 101: 392-397.

13. Passerotti CC, Kalish LA, Chow J, Passerotti AM, Recabal P, Cendron M, et al. The predictive value of the first postnatal ultrasound in children with antenatal hydronephrosis. J Pediatr Urol. 2011; 7(2): 128-36.

14. Stephens DF. Embryology of upper urogenital tract. In O'Donell B, Koff SA: Pediatric urology $3^{\text {rd }}$ ed. Oxford; Butterworth-Heinemann. 1997; 99-111.

15. Acton C, Pahuja M, Opie G, Woodward A. A 5-year audit of 778 neonatal renal scans (Part 2). Miscellaneous anomalies in 59 infants: a pictorial presentation. Australas Radiol. 2003; 47: 354-362.

16. Ahmad G, Green P. Outcome of fetal pyelectasis diagnosed antenatally. J Obstet Gynaecol. 2005; 25: 119-122.

17. Signorelli M, Cerri V, Taddei F, Groli C, Bianchi UA. Prenatal diagnosis and management of mild fetal pyelectasis: implications for neonatal outcome and 
follow-up. Eur J Obstet Gynecol Reprod Biol. 2005; 118: 154-159.

18. Sairam S, Al Habib A, Sasson S, Thilaganathan B. Natural history of fetal hydronephrosis diagnosed on mid-trimester ultrasound. Ultrasound Obstet Gynecol. 2001; 17: 191-196.

19. Chevalier R, Howards SS. Renal function in fetus, neonate, and child. In Walsh PC, Retic BA, Vaughan ED, Wein AJ: Campbell's Urology $8^{\text {th }}$ ed. CDROM Vol 3.Chapter 50. Philadelphia; Saunders, 2003.

20. Peters AC: Perinatal urology. In Walsh PC, Retic BA, Vaughan ED, Wein AJ. Campbell's Urology $8^{\text {th }}$ ed. CD-ROM Vol 3.Chapter 51. Philadelphia; Saunders, 2003.

21. Cendron M, Horton CE, Karim OMA, Takishima H, Haberlik A, Mostwin JL, Gearhart JP. A fetal lamb model of partial obstruction: experimental protocol and results. J Pediatr Surg. 1994; 29: 77-80.

22. Josephson S. Suspected pyelo-ureteral junction obstruction in fetus: When to do what? Experimental viewpoints. Eur Urol. 1991; 19: 132-138.

23. Sidhu G, Beyene J, Rosenblum ND. Outcome of isolated antenatal hydronephrosis: a systematic review and meta-analysis. Pediatr Nephrol. 2006; 21(2): 218-24.

24. Woodward M, Frank D. Postnatal management of antenatal hydronephrosis. BJU Int. 2002; 89: 149- 56.

25. Zerin JM, Ritchey ML, Chang AC. Incidental vesicoureteral reflux in neonates with antenatally detected hydronephrosis and other renal abnormalities. Radiology. 1993; 187: 157-60.

26. Mayor G, Genton N, Torrado A, Guignard JP. Renal function in obstructive nephropathy: long-term effect of reconstructive surgery. Pediatr. 1975; 56: 740-7.

27. Ransley PG, Dhillon HK, Gordon I, Duffy PG, Dillon MJ, Barrat TM. The postnatal management of hydronephrosis diagnosed by prenatal ultrasound. J Urol. 1990; 144: 584-7.

28. Blyth B. Snyder HM, Ducket JF. Antenatal hydronephrosis and subsequent management. J Urol. 1993; 149: 693-8.

29. Maizels M, Mitchell B, Kass E, Fernbach SK, Conway JJ. Outcome of nonspecific hydronephrosis in the infant: a report from the registry of the society for fetal urology. J Urol. 1994; 152: 2324-7.

30. Dhillon HK. Prenatally diagnosed hydronephrosis: the Great Ormond Street experience. Br J Urol. 1998; 81: 39-44.

31. Koff SA, Campbell KD. The nonoperative management of unilateral neonatal hydronephrosis: natural history of poorly functioning kidneys. J Urol. 1994; 152: 593-5.
Резиме

\section{КОНГЕНИТАЛНА ХИДРОНЕФРОЗА: БОЛЕСТ ИЛИ СОСТОЈБА?}

\section{Миле Петровски, Ристо Симеонов, Лазар Тодоровиќ, Владимир Чадиковски, Шабан Мемети, Бранка Петровска, Тони Ристески, Весна Цветановска}

Универзитетска клиника за детска хирургија, Медицински факултет, Универзитет „Св. Кирил и Методиј“, Скопје, Р. Македонија

Целта на овој труд е да се презентираат дилемите на детскиот хирург кога се сретнува со изолирана, унилатерална, конгенитална хидронефроза, како и да се обработат стратегиските опции за справување со оваа состојба.

Конгениталната хидронефроза е најчесто дијагностицирана уропатија кај децата. Во најголем број случаи претставува бенигна, самолимитирачка состојба. Неопструктивната хидронефроза не бара оперативен третман, додека кај опструктивните хидронефрози навремениот третман е императив за да се одбегне сигнификантно ренално оштетување. Менаџирањето на конгениталната хидронефроза претставува клинички предизвик.

Студијата опфаќа деца со изолирана, унилатерална хидронефроза и неопструктивни радиоренографски криви, следени во период од три години.

По првичната процена, 22,6\% од хидронефрозите беа од прв степен, 54,8\% од втор степен, а 22,6\% беа од трет степен. По 12 месеци, 30\% беа од прв степен, 51,5\% од втор степен, додека 18,5\% беа од трет степен. По тригодишно следење, ниедна од резидуалните хидронефрози не беше поголема од втор степен. Средната вредност на сепарантната GFR на засегнатиот бубрег изнесуваше 42,83\% при првичната процена и 40,33\% по три години. Кај три деца беше направена конверзија од конзервативен во хируршки третман.

Неопструктивната, конгенитална хидронефроза е бенигна состојба којашто не бара третман, но индицирано е агресивно следење на овие деца.

Клучни зборови: конгенитална хидронефроза, третман, дете. 